\title{
Ortho-nitrobenzyl derivatives as potential anti-schistosomal agents
}

\author{
Marcela Silva Lopes', Brian Michio Suzuki², Glaécia Aparecida do Nascimento Pereira ${ }^{3,4}$, \\ Alexandra Christina Probst ${ }^{2}$, Rafaela Salgado Ferreira ${ }^{3}$, Júlia Teixeira de Oliveira ${ }^{5}$, Kimberly Brito \\ Tecchio $^{5}$, Fabio Vieira dos Santos ${ }^{5}$, Conor Robert Caffrey², Renata Barbosa de Oliveira ${ }^{1 *}$
}

\begin{abstract}
${ }^{1}$ Pharmaceutical Products Department, Faculty of Pharmacy, Federal University of Minas Gerais, Belo Horizonte, Minas Gerais, Brazil, ${ }^{2}$ Center for Discovery and Innovation in Parasitic Diseases, Skaggs School of Pharmacy and Pharmaceutical Sciences, University of California San Diego, Gilman Drive, La Jolla, CA, USA, ${ }^{3}$ Biochemistry and Immunology Department, Biological Sciences Institute, Federal University of Minas Gerais, Belo Horizonte, Minas Gerais, Brazil, ${ }^{4}$ CAPES Foundation, Ministry of Education of Brazil, Brasilia, DF,Brazil, ${ }^{5}$ Laboratory of Cell Biology and Mutagenicity, Federal University of São João del Rei, Divinópolis, Minas Gerais, Brazil
\end{abstract}

\begin{abstract}
In the search for new anti-schistosomal agents, a series of fifteen ortho-nitrobenzyl derivatives was assayed in vitro against both the schistosomulum (somule) and adult forms of Schistosoma mansoni. Compounds $\mathbf{8}$ and $\mathbf{1 2}$ showed significant activity against somules at low micromolar concentrations, but none was active against adults. The SAR demonstrated that the compounds most active against the parasite were mutagenic to the human cell line RKO-AS45-1 only at concentrations 10- to 40-fold higher than the worm-killing dose. Given their electrophilicity, compounds were also screened as inhibitors of the $S$. mansoni cysteine protease (cathepsin B1) in vitro. Amides 5 and $\mathbf{1 5}$ exhibited a modest inhibition activity with values of 55.7 and $50.6 \%$ at $100 \mu \mathrm{M}$, respectively. The nitrobenzyl compounds evaluated in this work can be regarded as hits in the search for more active and safe anti-schistosomal agents.
\end{abstract}

Keywords: Nitro-aromatic. Schistosoma mansoni/anti-schistosomal activity. Cathepsin B1. Mutagenicity

\section{INTRODUCTION}

Schistosomiasis is a neglected tropical disease caused by a flatworm of the genus Schistosoma. The major species involved are $S$. haematobium, which causes the urogenital form of the disease, and $S$. mansoni and $S$. japonicum, which are responsible for the intestinal disease (Colley et al., 2014). An estimated 240 million people worldwide are infected by Schistosoma parasites and more than 700 million live in endemic areas (WHO, 2016a).

Praziquantel, a pyrazino-isoquinoline derivative (Figure 1), is registered as an essential medicine by the World Health Organization (WHO, 2016b) and is the first choice therapy for schistosomiasis. It is active against all schistosome species and is safe and inexpensive. However, concerns over the possible development of resistance to

\footnotetext{
*Correspondence: R. B. Oliveira. Departamento de Produtos Farmacêuticos, Faculdade de Farmácia, Universidade Federal de Minas Gerais. Av. Antônio Carlos 6627, CEP31270-901, Belo Horizonte, Minas Gerais, Brazil. E-mail: renatabo@farmacia.ufmg.br
}

praziquantel due to its large-scale use, motivates the search of new anti-schistosomal agents (Wang, Wang, Liang, 2012; Caffrey, 2015).<smiles>O=C(C1CCCCC1)N1CC(=O)N2CCc3ccccc3C2C1</smiles>

FIGURE 1 - Chemical structure of praziquantel.

Oxamniquine is a pro-drug that is activated by a Schistosoma sulfotransferase enzyme (Pica-Mattoccia et al., 2006). It is only clinically useful against $S$. mansoni infections (Caffrey, 2007; Axton, Garnett, 1976). The activated derivative is a nitro-aromatic compound that displays a good leaving group (sulfate) at the benzylic position. This product dissociates forming an electrophilic agent, which alkylates the parasite DNA (Abdul-Ghani et al., 2009) (Figure 2). 
<smiles>C=c1cc2c(cc1[N+](=O)[O-])=[NH+]C(CNC(C)C)CC2</smiles>

\section{activated oxamniquine}

FIGURE 2 - Oxamniquine mechanism of action.

Nitro-aromatic compounds, such as fexinidazole, benznidazole, and niclosamide, (Figure 3 ) are known for their pharmacological potential and our group has investigated the biological activities of a series of orthonitrobenzyl derivatives that act as alkylating agents (Lopes et al., 2015; Lopes et al., 2011; Soares et al., 2010).

Based on the need for new anti-schistosomal agents, we evaluated the schistosomicidal activity of nitro-aromatic compounds, analogs of "activated" oxamniquine, against $S$. mansoni in vitro. These compounds would be active per se, without the requirement for sulfotransferase activation, as proposed in Figure 4. Evidence suggests that oxamniquine-resistant schistosomes do not express the enzyme sulfotransferase and therefore cannot convert the oxamniquine into its active form (Valentim et al., 2013; Pica-Mattoccia et al., 2006). Therefore, compounds that are active per se could be an alternative in the treatment of oxamniquineresistant $S$. mansoni infections.

Based on their electrophilic characteristics, compounds were also assessed as possible inhibitors of S. mansoni cathepsin B1 (SmCB1), as this enzyme bears<smiles>CSc1ccc(OCc2ncc([N+](=O)[O-])n2C)cc1</smiles>

Fexinidazole<smiles>O=C(Cn1ccnc1[N+](=O)[O-])NCc1ccccc1</smiles>

Benznidazole<smiles>O=C(Nc1ccc([N+](=O)[O-])cc1Cl)c1cc(Cl)ccc1O</smiles>

Niclosamide

FIGURE 3 - Examples of nitro-aromatic drugs.
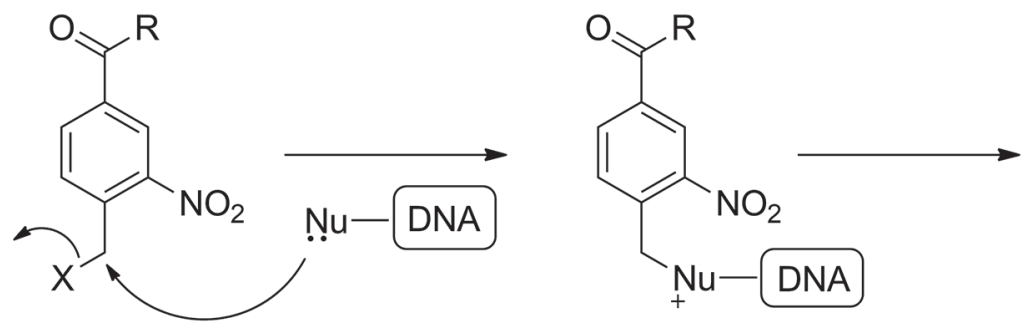

Alkylation of DNA of the parasite and prevents DNA replication

$\mathrm{R}=\mathrm{OH} ; \mathrm{NHR}^{\prime}$

$\mathrm{X}=$ leaving group

FIGURE 4 - Mechanism of action proposed for the ortho-nitrobenzyl derivatives synthesized. 
a nucleophilic cysteine residue in its active site (Jílková et al., 2011; Klinkert et al., 1989). SmCB1 is an abundant cysteine protease in the parasite (Caffrey et al., 1997; Caffrey, Ruppel, 1997), contributes to the digestion of hemoglobin in the schistosome gut (Caffrey et al., 2004; Sajid et al., 2003) and is an attractive drug target (Jílková et al., 2011; Abdulla et al., 2007).

However, as these nitrobenzyl derivatives act by DNA alkylation, studies to assess their mutagenicity were performed for a better comprehension of the possible genotoxic effects of these compounds on human host cells.

\section{MATERIAL AND METHODS}

\section{Synthesis}

The synthesis and characterization of the compounds 1-15 were previously described by us (Lopes et al., 2015). The compounds were synthesized in 1 to 3 steps from commercially available starting materials ( $p$-toluic acid, 4-(bromomethyl)benzoic acid or 4-(chloromethyl)benzoic acid) (Figure 5).

\section{In vitro screening of $S$. mansoni somules and adult worms}

Maintenance of the S. mansoni life cycle, preparation of somules and adult worms, compound storage, and treatment of somules and adult worms were as described (Abdulla et al., 2009; Colley, Wikel, 1974; Duvall, DeWitt, 1967). Somules were cultured for four days in the presence of compounds at three concentrations, $0.1,1.0$ and $10 \mu \mathrm{M}$. Adults (approximately 5 pairs) were cultured for two days in the presence of $5 \mu \mathrm{M}$ compound. We employ simple descriptors to describe the observable effects of compounds on the parasite (changes in shape, motility and general appearance; Table I) (Rojo-Arreola et al., 2014; Abdulla et al., 2009). To convert these observations into a partially quantitative output in order to facilitate relative comparisons of compound effects, each descriptor is awarded a score of 1 up to a maximum score of 4 (Table I; Fonseca et al., 2015; Long et al., 2016). Evidence of degeneracy or death was awarded the maximum score of 4 . Death was adjudicated as the lack of parasite movement over a continuous $30 \mathrm{sec}$ viewing period after tilting of the plate in order to agitate the parasite. For adults, damage to the tegument (outer surface) was awarded a score of 4 on the understanding that surface damage is lethal to the parasite in vivo (Andrews et al., 1983).

\section{Enzymatic assays against the cathepsin B1 of Schistosoma mansoni (SmCB1)}

The recombinant SmCB1 was expressed and purified as previously described (Sajid et al., 2003). The enzyme activity was measured by monitoring the cleavage of a fluorogenic substrate, Z-Phe-Arg-aminomethylcoumarin (Z-FR-AMC), with 340/440 nm excitation/emission filters, in a microplate reader Synergy 2 (Biotek ${ }^{\circledR}$ ) from the Center of Flow Cytometry and Fluorimetry at the Biochemistry and Immunology Department (UFMG). To determine the initial reaction rates, fluorescence was monitored at $25^{\circ} \mathrm{C}$, for 20 minutes at $12 \mathrm{~s}$ intervals at 340/440 nm excitation/emission, using BioTek's Gen5 $5^{\mathrm{TM}}$ Reader Control and Data Analysis Software. Assays were performed using $20 \mu \mathrm{M}$ substrate and $8 \mathrm{nM}$ SmCB1 in sodium acetate buffer $0.1 \mathrm{M}, \mathrm{pH} 5.5$, containing $0.01 \%$ Triton X-100 and $4 \mathrm{mM} \beta$-mercaptoethanol. In all assays, a $1 \%$ DMSO negative control and a 100nM E-64 positive control (E-64 is an inhibitor of cysteine proteases like SmCB1) were employed. Enzyme inhibition was calculated based on initial rates compared to the DMSO control. Compound stock solutions were prepared in DMSO. $1 \mu \mathrm{L}$ of the $20 \mathrm{mM}$ DMSO stock solution was added to each well, to a total volume of $200 \mu \mathrm{L}$ in buffer assay, resulting in a final concentration of $100 \mu \mathrm{M}$ of the compound and $1 \%$ DMSO in the assay. All compounds were soluble at the screening concentration and conditions. Compounds were screened with or without pre-incubation with the enzyme, for $10 \mathrm{~min}$ with the enzyme at room temperature. All assays were performed in at least two independent experiments, each in triplicate.

\section{Cytokinesis-Block Micronucleus (CBMN) Assay}

To assess the potential of the nitrobenzyl compounds 4, 8 and 12 to induce chromosomal mutations in vitro, the cytokinesis-block micronucleus assay (CBMN) was performed in the RKO-AS45-1 (ATCC CRL-2577) human cell line. The procedures were carried out as described by Fenech (2007), with adaptations (Gontijo et al., 2015). Briefly, the cells were seeded in 24-well plates $\left(2.5 \times 10^{5}\right.$ cells/well $)$ and maintained at $37^{\circ} \mathrm{C}$ in a humid atmosphere with $5 \% \mathrm{CO}_{2}$. After 24 hours, the cells were washed twice with PBS and the treatments were performed in culture medium without serum for three hours. Each treatment was performed in triplicate and three independent experiments for each compound were carried out in this study. Four different concentrations (5, 10,20 e $40 \mu \mathrm{M}$ ) of the compounds $\mathbf{4 , 8}$ and $\mathbf{1 2}$, diluted in culture medium, were evaluated. The negative control 


$$
\begin{aligned}
& \text { activated oxamniquine: } \mathrm{R}_{1} \text { and } \mathrm{R}_{2}=\underbrace{\mathrm{R}}_{\mathrm{Me}} \\
& \text { nitroaromatic compounds: } \\
& 1 \mathrm{R}_{1}=-\mathrm{COOH}, \mathrm{R}_{2}=\mathrm{H}, \mathrm{R}_{3}=\mathrm{Br} \\
& 2 \mathrm{R}_{1}=-\mathrm{COOH}, \mathrm{R}_{2}=\mathrm{H}, \mathrm{R}_{3}=\mathrm{Cl} \\
& 3 \mathrm{R}_{1}=-\mathrm{COOH}, \mathrm{R}_{2}=\mathrm{H}, \mathrm{R}_{3}=\mathrm{H} \\
& 8 \mathrm{R}_{1}= \\
& 4 \mathrm{R}_{1}={ }_{2} \\
& 5 \mathrm{R}_{1}={ }_{2} \sim \mathrm{OH}, \mathrm{R}_{2}=\mathrm{H}, \mathrm{R}_{3}=\mathrm{Br} \\
& 6 \mathrm{R}_{1}=-\mathrm{COOH}, \mathrm{R}_{2}=\mathrm{H}, \mathrm{R}_{3}=\mathrm{OH} \\
& 9 \mathrm{R}_{1}={ }_{2} \\
& 10 \mathrm{R}_{1}={ }_{z_{2}} \mathrm{OOH}, \mathrm{R}_{2}=\mathrm{H}, \mathrm{R}_{3}=\mathrm{H}^{s^{5}} \\
& 11 \mathrm{R}_{1}=\underbrace{}_{2} \mathrm{OHOH}_{\mathrm{N}}^{\mathrm{OH}} \mathrm{R}_{2}=\mathrm{H}, \mathrm{R}_{3}=\xi-\mathrm{O} \\
& 12 \mathrm{R}_{1}=\mathrm{R}_{\mathrm{H}}^{\mathrm{O}}, \mathrm{H}, \mathrm{R}_{3}=\mathrm{Cl}
\end{aligned}
$$

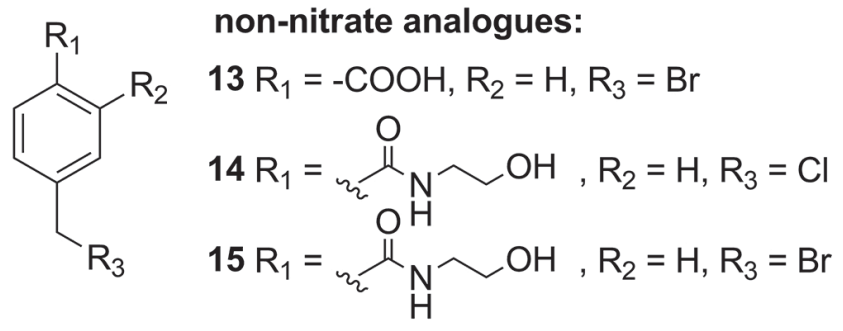

\section{General synthesis scheme}

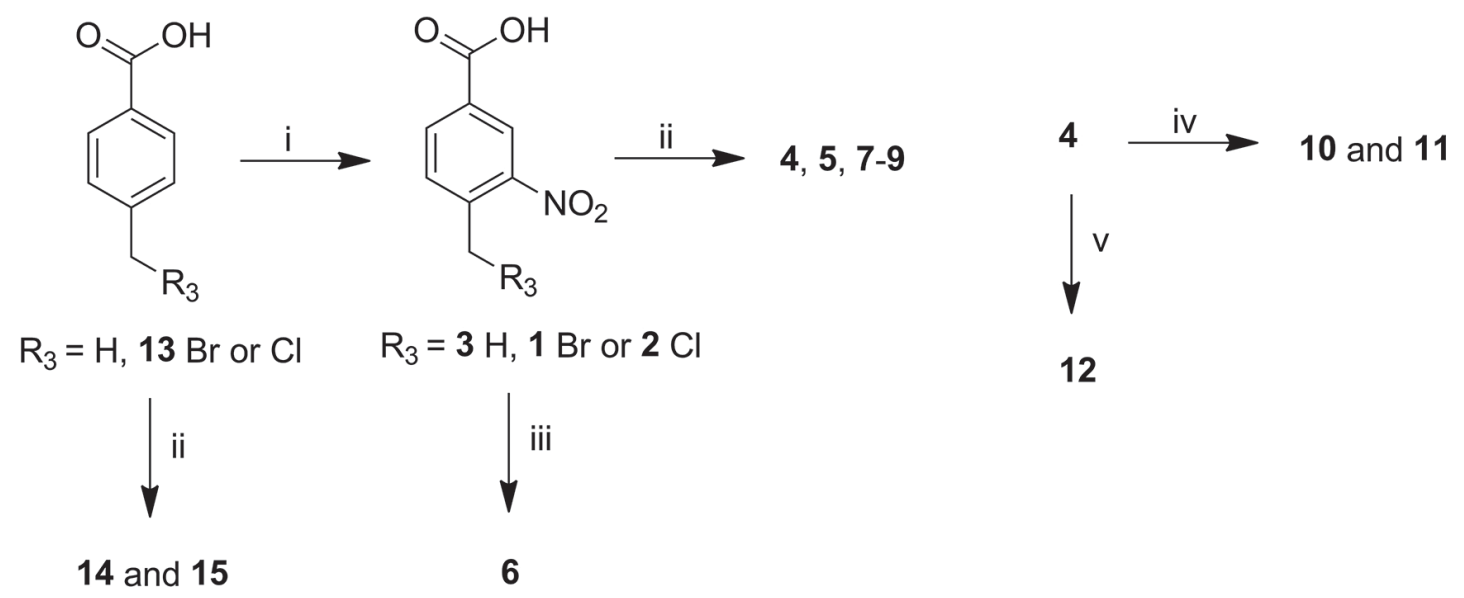

FIGURE 5 - Synthesized nitro-aromatic compounds and non-nitrate analogs and general synthesis scheme. Reagents and conditions: (i) fuming $\mathrm{HNO} 3,0^{\circ} \mathrm{C}, 51-87 \%$; (ii) $\mathrm{EDC}$, NHS, dichloromethane, rt or $0{ }^{\circ} \mathrm{C}$, then corresponding amines, 22-74\%; (iii) $\mathrm{NaHCO}_{3}(\mathrm{aq})$, $80{ }^{\circ} \mathrm{C}, 86 \%$; (iv) tetrahydroisoquinoline (56\%) or morpholine (64\%), acetone, rt,; (v) butyric acid, EDC, DMAP, acetone, rt, $87 \%$.

group was treated with culture medium without serum, and a positive control group was established by treatment with methyl methanesulphonate (MMS - $400 \mu \mathrm{M}$ ). After completing the treatments, cells were washed twice with PBS and fresh complete medium containing
cytochalasin-B $(3.0 \mu \mathrm{g} / \mathrm{mL})$ was added for $24 \mathrm{~h}$. Next, the cells were processed, fixed and the slides were stained with DAPI (4',6-diamidino-2-phenylindole - $1 \mu \mathrm{g} / \mathrm{mL}$ ) diluted in PBS. The microscopic analysis was performed with a fluorescent microscope (Zeiss, Axioscope A1) 
with an excitation filter of $365 \mathrm{~nm}$ and a barrier filter of $445 / 450 \mathrm{~nm}$. One thousand binucleated cells with a wellpreserved cytoplasm were analyzed for each treatment in a blind test. Cells containing 1-3 micronuclei were scored (Gomes et al., 2011). The criterion for the identification of micronuclei (MNs) was according to a previous report (Titenko-Holland et al., 1997). For statistical analysis, ANOVA was performed followed by the Tukey post-test with a significance level of 0.05 .

\section{Nuclear Division Index (NDI)}

The influence of the synthetic compounds on cell proliferation was assessed by calculating the nuclear division index (NDI) in RKO-AS45-1. The same slides prepared for the CBMN assay were used, and 300 cells with a well-preserved cytoplasm were counted using fluorescence microscopy, as described above. The NDI was calculated according to Fenech (2007) and Eastmond and Tucker (1989), using the equation:

$$
\mathrm{NDI}=\frac{(\mathrm{M} 1+2(\mathrm{M} 2)+3(\mathrm{M} 3)+4(\mathrm{M} 4))}{\mathrm{N}}
$$

where M1-M4 are the numbers of cells with 1, 2, 3 and 4 nuclei, respectively, and $\mathrm{N}$ is the total number of counted cells. For statistical analysis, ANOVA was performed followed by the Tukey post-test with a significance level of 0.05 .

\section{RESULTS AND DISCUSSION}

Compounds 1-15 were synthesized according to previously reported procedures (Lopes et al., 2015) based on variations at the $R_{1}, R_{2}$ and $R_{3}$ positions of sulfateoxamniquine (Figure 5). We tested the effect of different substituents at the benzylic $\left(-\mathrm{R}_{3}\right)$ position because it is expected that the mechanism of action is by DNA alkylation. Analogues without the nitro group $(\mathbf{1 3}, 14$ and 15) were also assessed in order to evaluate the importance of this group for schistosomicidal activity.

Compounds were screened for in vitro schistosomicidal activity against somules and adult $S$. mansoni as described above. The data for active compounds are presented in Table I.

Three compounds $(\mathbf{4}, \mathbf{8}$ and $\mathbf{1 2})$ elicited progressive and deleterious phenotypic alterations in $S$. mansoni somules: compounds $\mathbf{8}$ and $\mathbf{1 2}$ were the most potent. Both compounds caused degeneration of the parasites within 24 $\mathrm{h}$ at 10 and $1 \mu \mathrm{M}$. These changes were eventually lethal. Effects (darkening of the parasite) were also noted at $0.1 \mu \mathrm{M}$ on the third day. As a comparator, oxamniquine induced less pronounced degenerative changes within 24 $\mathrm{h}$ at 10 and $1 \mu \mathrm{M}$. Effects (slowing and darkening of the parasite) were also noted at $0.1 \mu \mathrm{M}$ on the third day.

Taking into account that the mode of action of these compounds is by alkylation, it would be expected that compounds bearing a good leaving group, such as bromine and chlorine, to be the most potent. However, all compounds containing a bromine substituent were inactive. This can be explained by the lower stability of the bromo benzyl group in the assay medium. Thus, our results indicate that the chlorine leaving group shows the best apparent trade-off between activity and stability. As expected, compounds without a leaving group at the benzylic position $(\mathbf{3}, \mathbf{6}, \mathbf{9}, \mathbf{1 0}$ and $\mathbf{1 1})$ showed no activity.

In contrast to the result obtained for compound $\mathbf{4}$, the corresponding non-nitrated analog 14 did not display

TABLE I - Descriptors ${ }^{\mathrm{a}}$ and severity scores ${ }^{\mathrm{b}}$ for the responses of $S$. mansoni somules and adults to nitrobenzyl compounds $\mathbf{4 , 8}$ and $\mathbf{1 2}$

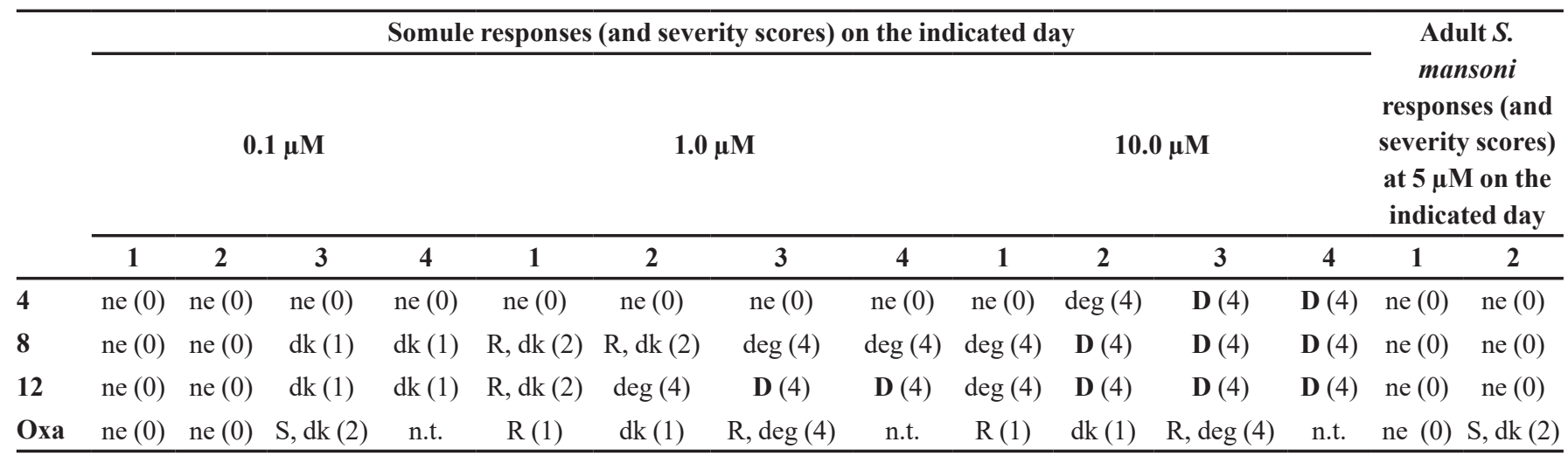

${ }^{a}$ Descriptors: $\mathrm{ne}=$ no effect, $\mathrm{dk}=$ dark, $\mathrm{R}=$ shape altered, $\mathrm{deg}=$ degenerating, $\mathbf{D}=$ death, $\mathrm{S}=$ slow, n.t. $=$ not tested. ${ }^{\mathrm{b}}$ Each descriptor is awarded a 'severity score' of 1 (in parentheses) and these are added up to the maximum score of 4 . The descriptors 'deg' and 'D' are automatically awarded a score of 4 . Oxa $=$ oxamniquine. 
activity, suggesting a positive influence of nitro group on reactivity and activity. The electron-withdrawing character of this group may be associated with an increased electrophilicity of the benzylic carbon thereby promoting alkylation.

Regarding the substituent at $\mathrm{R}_{1}$, compounds having a carboxylic acid group showed no activity against $S$. mansoni somules whereas amides containing a hydrogen bond acceptor atom in the side chain showed relevant activity. The morpholine-amide 8 was more potent than ethanolamide (4) and propylamide (7) analogs. Esterification of the hydroxyl group of 4 with butyric acid resulted in significant increase of activity.

These findings are in agreement with our previous studies (Lopes et al., 2015) which have indicated the importance of the presence of a good leaving group at the benzylic position for the antiproliferative activity these compounds on different human cancer cell lines $\left(\mathrm{IC}_{50}\right.$ ranging from 1.3 to $83.4 \mu \mathrm{M}$ ). However, unlike the results presented here, compounds bearing a benzyl bromide were cytotoxic for cancer cells independent of the presence of the nitro group.

In summary, the results found in the present study indicate that: a) the presence of a leaving group at the benzylic position is essential for the antishistosomal activity; b) the presence of a nitro group is also indispensable for the activity; c) compounds containing an amide group are more active than those containing a carboxylic acid group; d) compounds bearing a hydrogen bond acceptor atom in the side chain display higher activity. These assumptions are illustrated in Figure 6.

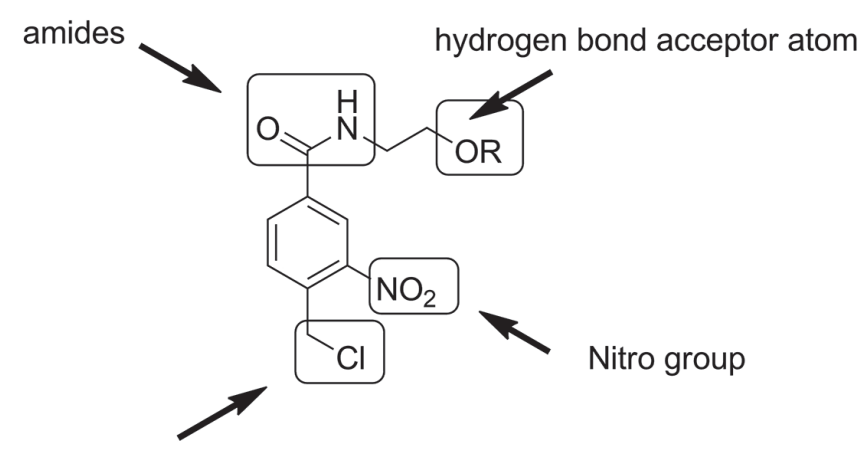

chlorine benzyl group

FIGURE 6 - Key functional groups important for antischistosomal activity.

Despite the results obtained in the somule assay, none of the compounds showed activity against the adult worm. In contrast, oxamniquine induced degenerative changes in adults on the second day of the incubation (Table I). The lack of activity may be due to an inability of the compounds to cross the adult parasite tegument (surface) and/or differences in expression of potential targets. Structural differences in the outer membrane of larval and adult stages are known (Hockley, McLaren, 1973). Also, differences in transcriptome expression profiles between developmental stages of the parasite, including between somules and adults are well documented (Liu et al., 2014; Liu et al., 2006; Verjovski-Almeida et al., 2003). Modifications of the physicochemical properties of compounds could be performed in an attempt to enhance their membrane permeability.

Alkylating agents are potentially carcinogenic compounds that can introduce lesions at DNA nucleophilic centers (Sobol et al., 2007) and can cause clastogenic effects and, consequently micronuclei formation. Micronuclei are small, extranuclear chromatin bodies surrounded by a nuclear envelope, which arise in dividing cells from acentric chromosome fragments or whole chromosomes. They result in chromosomal alterations that have been transmitted to daughter cells and are frequently used as an endpoint in genotoxicity testing (Hintzchea et al., 2017). OECD guidelines (OECD, 2016) suggest the use of the micronucleus assay to assess the risks associated with potential clastogenic/aneugenic compounds and the FDA recommends the micronucleus assay in the test battery for genotoxicity testing of Pharmaceuticals (FDA, 2016).

As compounds 4, 8 and $\mathbf{1 2}$ are active per se it was necessary to evaluate their genotoxicity on a mammalian cell line. The CBMN assay was carried out using the human cell line RKO-AS45-1 (ATCC CRL-2577) and results are shown in Figure 7. Compound 4 was mutagenic only in the highest concentration assessed $(40 \mu \mathrm{M})$ and the NDI was not altered in any concentration assessed. Compound 8 also induced chromosomal mutations on human cell line at $40 \mu \mathrm{M}$ but the NDI was altered at 20 and $40 \mu \mathrm{M}$, indicating a reduction in proliferation rate at these conditions. Compound $\mathbf{1 2}$ was able to induce DNA damages in concentrations ranging $10-40 \mu \mathrm{M}$ but the NDI was reduced only at 20 and $40 \mu \mathrm{M}$.

These results showed that the ortho-nitrobenzyl halides really have a mutagenic effect, probably due to their alkylating potential. However, the concentrations needed to induce genotoxic effects in the human cell line used was much higher than those necessary to induced phenotypic alterations and death in S. mansoni (Table II). Furthermore, the alterations of the NDI observed to the compounds $\mathbf{8}$ and $\mathbf{1 2}$ showed that the human cells used responded to the damages induced by the compounds, probably arresting the cell cycle to promote the DNA repair. Unlike these compounds, studies indicate that 

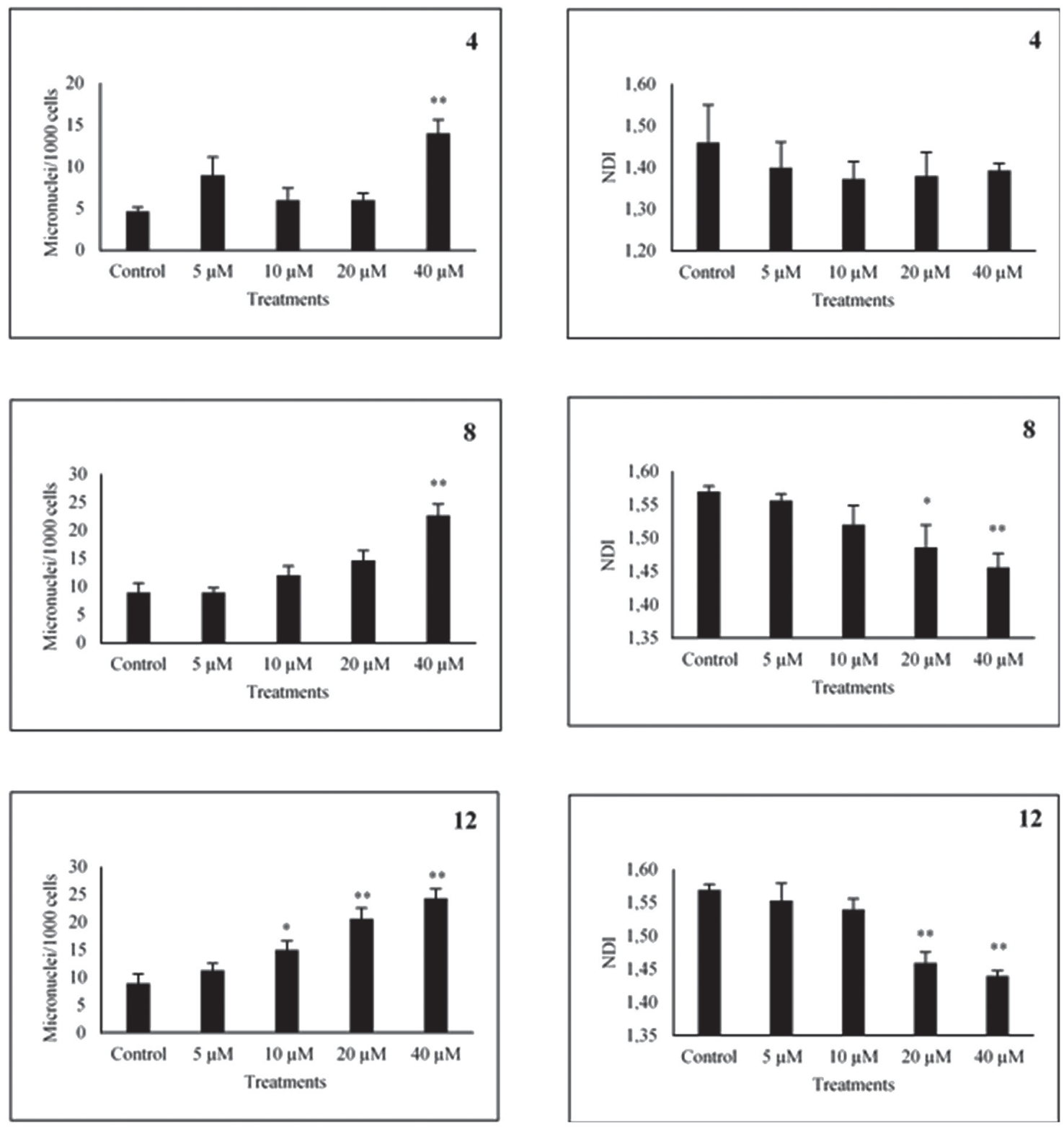

FIGURE 7 - Mean and standard deviation of the frequency of micronuclei in binucleated cells and nuclear division index (NDI) after the treatment of RKO-AS45-1 human cell line with the compounds 4, 8 and 12 (incubation time $=3$ hours). Three independent experiments were performed to each compound. ${ }^{*} \mathrm{p}<0.05$ and ${ }^{* *} \mathrm{p}<0.01$ when compared with the control. MMS $=$ Methyl methanesulfonate $(400 \mu \mathrm{M})$.

the oxamniquine has low mutagenic potential (Ray et al. 1975), although there are reports of its mutagenic effect when tested on Salmonella typhimurium strain TA100 (Batzinger, Bueding, 1977; Dayan, Deguingand, Truzman, 1985).

Given the electrophilic nature of these derivatives and the nucleophilic character of catalytic cysteine in the protease $\mathrm{SmCB} 1$, these compounds were also evaluated against this enzyme, a pharmacological target for schistosomiasis (Jíková et al., 2011; Caffrey et al., 1997). In order to evaluate their ability to inhibit SmCB1,
TABLE II - In vitro effect of $\mathbf{4 , 8}$ and $\mathbf{1 2}$ against $S$. mansoni somules and the least concentration necessary to induce genotoxicity

\begin{tabular}{ccc}
\hline Compound & $\begin{array}{c}\text { Schistosomicidal } \\
\text { activity }(\boldsymbol{\mu M})^{*}\end{array}$ & $\begin{array}{c}\text { Mutagenic } \\
\text { Concentration }(\boldsymbol{\mu M})\end{array}$ \\
\hline $\mathbf{4}$ & 10.0 & 40.0 \\
$\mathbf{8}$ & 1.0 & 40.0 \\
$\mathbf{1 2}$ & 1.0 & 10.0 \\
\hline
\end{tabular}

${ }^{*}$ Concentration of compound at which the maximum severity score of 4 is achieved. 
compounds 1-15 were screened in vitro at $100 \mu \mathrm{M}$ with and without a pre-incubation period with the enzyme prior to addition of substrate (Table III). Most compounds were weak inhibitors of SmCB1 and appear to be slightly more effective when pre-incubated with the enzyme. Although $o$-nitrobenzyl derivatives present an electrophilic character and can potentially bind covalently to the cysteine residue, in order to do so they need to have sufficient affinity for enzyme active site. Thus, it is supposed that these compounds are not able to inhibit SmCB1 due to their poor complementarity to the enzyme's active site. Amides 5 and 15 showed the best results, with moderate inhibitory activity ( 55 and $50 \%$ respectively) with pre-incubation. These compounds have in common the ethanolamine chain and the bromine atom at the benzylic position. Further SAR studies are necessary to obtain compounds with more affinity and activity against SmCB1.

TABLE III - Inhibitory activity of 1-15 against SmCB1

\begin{tabular}{ccc}
\hline \multirow{2}{*}{ Compound } & \multicolumn{2}{c}{ \% inhibition at $\mathbf{1 0 0} \boldsymbol{\mu} \mathbf{M} \pm \mathbf{S D}^{*}$} \\
\cline { 2 - 3 } & without incubation & with incubation \\
\hline $\mathbf{1}$ & $4.4 \pm 1.6$ & $24.3 \pm 6.0$ \\
$\mathbf{2}$ & $4.3 \pm 0.8$ & $0.0 \pm 0.0$ \\
$\mathbf{3}$ & $3.3 \pm 3.8$ & $1.1 \pm 2.0$ \\
$\mathbf{4}$ & $14.5 \pm 2.4$ & $30.5 \pm 2.9$ \\
$\mathbf{5}$ & $14.7 \pm 0.0$ & $55.7 \pm 20.7$ \\
$\mathbf{6}$ & $0.0 \pm 0.0$ & $17.3 \pm 3.7$ \\
$\mathbf{7}$ & $0.4 \pm 0.6$ & $27.4 \pm 1.0$ \\
$\mathbf{8}$ & $4.7 \pm 4.8$ & $26.5 \pm 12.3$ \\
$\mathbf{9}$ & $0.0 \pm 0.0$ & $4.6 \pm 5.0$ \\
$\mathbf{1 0}$ & $2.1 \pm 1.0$ & $44.5 \pm 18.5$ \\
$\mathbf{1 1}$ & $7.3 \pm 2.9$ & $11.1 \pm 5.6$ \\
$\mathbf{1 2}$ & $27.1 \pm 0.4$ & $19.9 \pm 3.3$ \\
$\mathbf{1 3}$ & $15.6 \pm 1.8$ & $26.5 \pm 0.1$ \\
$\mathbf{1 4}$ & $5.7 \pm 1.0$ & $16.5 \pm 2.6$ \\
$\mathbf{1 5}$ & $6.1 \pm 0.2$ & $50.6 \pm 2.4$ \\
$\mathbf{E 6 4}$ & $55.4 \pm 5.6^{\mathrm{a}}$ & $82.5 \pm 9.9^{\mathrm{a}}$ \\
\hline
\end{tabular}

*All reported percentages of inhibition were calculated based on DMSO controls, which were included in every assay and considered as $100 \%$ activity. SD $=$ Standard Deviation. ${ }^{\mathrm{a}}$ Evaluated at $100 \mathrm{nM}$.

\section{CONCLUSION}

In conclusion, the ortho-nitrobenzyl derivatives $\mathbf{8}$ and $\mathbf{1 2}$ showed significant activity against somules in vitro. A structure-activity relationship could be established with the identification of key functional groups of these alkylating agents. However, it was interesting to observe that they triggered the death of $S$. mansoni somules at lower concentrations than those that induced chromosomal mutations in human cells in vitro. Nevertheless, none of the compounds was active against the adult parasite in vitro and further modifications are needed to find analogs that display activity against both life stages of S. mansoni. None of the compounds efficiently inhibited SmCB1 in vitro.

\section{ACKNOWLEDGEMENTS}

We are grateful to Fundação de Amparo à Pesquisa de Minas Gerais (FAPEMIG), Conselho Nacional de Desenvolvimento Científico e Tecnológico (CNPq) and Coordenação de Aperfeiçoamento de Pessoal de Nível Superior (CAPES) for financial support. Schistosome phenotypic screening at the CDIPD was supported in part by NIH-NIAID grants R21AI126296 and R21AI133393.

\section{REFERENCES}

Abdul-Ghani R, Loutfy N, Sahn AE, Hassan A. Current chemotherapy arsenal for schistosomiasis mansoni: alternatives and challenges. Parasitol Res. 2009;104(5):955-965.

Abdulla MH, Lim KC, Sajid M, McKerrow JH, Caffrey CR. Schistosomiasis mansoni: novel chemotherapy using a cysteine protease inhibitor. PLoS Med. 2007;4(1):e14,0130-0138.

Abdulla MH, Ruelas DS, Wolff B, Snedecor J, Lim KC, Xu F, et al. Drug discovery for schistosomiasis: hit and lead compounds identified in a library of known drugs by medium-throughput phenotypic screening. PLoS Negl Trop Dis. 2009;3(7):e478,114.

Andrews P, Thomas H, Pohlke R, Seubert J. Praziquantel. Med Res Rev. 1983;3(2):147-200.

Axton JH, Garnett PA. A trial of oral oxamniquine in the treatment of Schistosoma infection in children. S Afr Med J. 1976;50(27):1051-1053.

Batzinger RP, Bueding E. Mutagenic activities in vitro and in vivo of five antischistosomal compounds. J Pharm Exp Ther. 1977;200:1-9. 
Caffrey CR, Rheinberg CE, Moné H, Jourdane J, Li YL, Ruppel A. Schistosoma japonicum, S. mansoni, S. haematobium, S. intercalatum, and $S$. rodhaini: cysteine-class cathepsin activities in the vomitus of adult worms. Parasitol Res. 1997;83(1):37-41.

Caffrey CR, Ruppel A. Cathepsin B-like activity predominates over cathepsin L-like activity in adult Schistosoma mansoni and S. japonicum. Parasitol Res. 1997;83(6):632-635.

Caffrey CR, McKerrow JH, Salter JP, Sajid M. Blood 'n' guts: an update on schistosome digestive peptidases. Trends Parasitol. 2004;20(5):241-248.

Caffrey CR. Chemotherapy of schistosomiasis: present and future. Curr Opin Chem Biol. 2007;11(4):433-439.

Caffrey CR. Schistosomiasis and its treatment. Future Med Chem. 2015;7(6):675-676.

Colley DG, Wikel SK. Schistosoma mansoni: simplified method for the production of schistosomules. Exp Parasitol. 1974;35(1):44-51.

Colley DG, Bustinduy AL, Secor WE, King CH. Human schistosomiasis. Lancet. 2014;383(9936):2253-2264.

Dayan J, Deguingand S, Truzman C. Study of the mutagenic activity of 6 hepatotoxic pharmaceutical drugs in the Salmonella typhimurium microsome test, and the HGPRT and $\mathrm{Na}+$ / $\mathrm{K}+$ ATPase system in cultured mammalian cells. Mutat Res. 1985;157:1-12.

Duvall RH, DeWitt WB. An improved perfusion technique for recovering adult schistosomes from laboratory animals. Am J Trop Med Hyg. 1967;16(4):483-486.

Eastmond DA, Tucker JD. Identification of aneuploidyinducing agents using cytokinesis-blocked human lymphocytes and an antikinetochore antibody. Environ Mol Mutagen. 1989;13(1):34-43.

Fenech M. Cytokinesis-block micronucleus cytometry assay. Nat Protoc. 2007;2(5):1084-1104.

Fonseca NC, Cruz LF, Vilela FS, Pereira GAN, Siqueira-Neto JL, Kellar D, et al. Synthesis of a sugar-based thiosemicarbazone series and structure-activity relationship versus the parasite cysteine proteases rhodesain, cruzain, and Schistosoma mansoni cathepsin B1. Antimicrob Agents Chemother. 2015;59(5):26662677.
Food and Drugs Administration. FDA. S2B Genotoxicity: A Standard Battery for Genotoxicity Testing of Pharmaceuticals. [cited 2016 Sept 25]. Available from: https://www.fda.gov/ downloads/drugs/guidancecomplianceregulatoryinformation/ guidances/ucm074929.pdf.

Gomes CC, Moreira LM, Santos VJSV, Ramos AS, Lyon JP, C. P. Soares CP, et al. Assessment of the genetic risks of a metallic alloy used in medical implants. Genet Mol Biol. 2011;34(1):116121.

Gontijo VS, Espuri PF, Alves RB, Camargos LF, Santos FV, Judice WA, et al. Leishmanicidal, antiproteolytic, and mutagenic evaluation of alkyltriazoles and alkylphosphocholines. Eur J Med Chem. 2015;101:24-33.

Hintzschea H, Hemmann U, Poth A, Utesch D, Lott J, Stopper $\mathrm{H}$. Fate of micronuclei and micronucleated cells. Mutat Res. 2017;771:85-98.

Hockley DJ, McLaren DJ. Schistosoma mansoni: changes in the outer membrane of the tegument during development from cercaria to adult worm. Int J Parasitol. 1973;3(1):13-25.

Jílková A, Rezácová P, Lepsík M, Horn M, Váchová J, Fanfrlík $\mathrm{J}$, et al. Structural basis for inhibition of cathepsin B drug target from the human blood fluke, Schistosoma mansoni. J Biol Chem. 2011;286(41):35770-35781.

Klinkert MQ, Felleisen R, Link G, Ruppel A, Beck E. Primary structures of Sm31/32 diagnostic proteins of Schistosoma mansoni and their identification as proteases. Mol Biochem Parasitol. 1989;33(2):113-122.

Liu F, Lu J, Hu W, Wang SY, Cui SJ, Chi M, et al. New perspectives on host-parasite interplay by comparative transcriptomic and proteomic analyses of Schistosoma japonicum. PLoS Pathog. 2006;2(4):e29,0268-0281.

Liu S, Cai P, Piao X, Hou N, Zhou X, Wu C, et al. Expression profile of the Schistosoma japonicum degradome reveals differential protease expression patterns and potential antischistosomal intervention targets. PLoS Comput Biol. 2014;10(1):e1003856,1-13.

Long T, Neitz RJ, Beasley R, Kalyanaraman C, Suzuki BM, Jacobson MP, et al. Structure-bioactivity relationship for benzimidazole thiophene inhibitors of polo-like kinase 1 (PLK1), a potential drug target in Schistosoma mansoni. PLoS Negl Trop Dis. 2016;10(1):e0004356. 
Lopes MS, Pietra RCCS, Borgati TF, Romeiro CFD, Júnior PAS, Romanha AJ, et al. Synthesis and evaluation of the anti parasitic activity of aromatic nitro compounds. Eur J Med Chem. 2011;46(11):5443-5447.

Lopes MS, Sena CFA, Silva BL, Souza CM, Ramos JP, Cassali GD, et al. Synthesis of nitroaromatic compounds as potential anticancer agents. Anticancer Agents Med Chem. 2015;15(2):206-216.

OECD - OECD Guideline for the testing of chemicals - in vitro mammalian cell micronucleus test. [cited 2016 Sept 25]. Available from: https:/ntp.niehs.nih.gov/iccvam/suppdocs/ feddocs/oecd/oecd-tg487-2014-508.pdf.

Pica-Mattoccia L, Carlini D, Guidi A, Cimica V, Vigorosi F, Cioli D. The schistosome enzyme that activates oxamniquine has the characteristics of a sulfotransferase. Mem Inst Oswaldo Cruz. 2006;101(suppl 1):307-312.

Ray VA, Holden HE, Ellis JHJr, Hyneck ML. A comparative study on the genetic effects of hycanthone and oxamniquine. J Toxicol Environ Health. 1975;1(2):211-217.

Rojo-Arreola L, Long T, Asarnow D, Suzuki BM, Singh R, Caffrey CR. Chemical and genetic validation of the statin drug target to treat the helminth disease, schistosomiasis. PLoS One. 2014;9(1):e87594,1-11.

Sajid M, McKerrow JH, Hansell E, Mathieu MA, Lucas KD, Hsieh I, et al. Functional expression and characterization of Schistosoma mansoni cathepsin B and its trans-activation by an endogenous asparaginyl endopeptidase. Mol Biochem Parasitol. 2003;131(1):65-75.

Soares GA, Oliveira RB, Andrade SF, Alves RJ, Zani CL, Souza-Fagundes EM. Synthesis and in vitro cytotoxic activity of compounds with pro-apoptotic potential. Molecules. 2010;15(1):12-26.
Sobol Z, Engel ME, Rubitski E, Ku WW, Aubrecht J, Schiestl RH. Genotoxicity profiles of common alkyl halides and esters with alkylating activity. Mutat Res. 2007;633(2):80-94.

Titenko-Holland N, Windham G, Kolachana P, Reinisch F, Parvatham S, Osorio AM, et al. Genotoxicity of malathion in human lymphocytes assessed using the micronucleus assay in vitro and in vivo: A study of malathion-exposed workers. Mutat Res. 1997;388(1):85-95.

Valentim CL, Cioli D, Chevalier FD, Cao X, Taylor AB, Holloway SP, et al. Genetic and molecular basis of drug resistance and species-specific drug action in schistosome parasites. Science. 2013;342(6164):1385-1389.

Verjovski-Almeida S, DeMarco R, Martins EA, Guimarães PE, Ojopi EP, Paquola AC, et al. Transcriptome analysis of the acoelomate human parasite Schistosoma mansoni. Nat Genet. 2003;35(2):148-157.

Wang W, Wang L, Liang YS. Susceptibility or resistance of praziquantel in human schistosomiasis: a review. Parasitol Res. 2012;111(5):1871-1877.

World Health Organization. WHO. Schistosomiasis. [Cited 2016a Aug 24]. Available from: http://www.who.int/ schistosomiasis/en/.

World Health Organization. WHO. WHO model list of essentials medicines. $19^{\text {th }}$ list (april 2015). [cited 2016b Sept 3]. Available from: http://www.who.int/medicines/publications/ essentialmedicines/EML_2015_FINAL_amended_NOV2015. pdf?ua $=1$.

Received for publication on $26^{\text {th }}$ June 2017 Accepted for publication on $02^{\text {nd }}$ November 2017 